\title{
The Coming of an Ice Age? Turkish-Israeli Relations Since 2002
}

\section{ilker Aytürk}

To cite this article: Ilker Aytürk (2011) The Coming of an Ice Age? Turkish-Israeli Relations Since 2002, Turkish Studies, 12:4, 675-687, DOI: 10.1080/14683849.2011.622507

To link to this article: http://dx.doi.org/10.1080/14683849.2011.622507

$$
\text { 电 Published online: } 12 \text { Dec } 2011 .
$$

Submit your article to this journal $[\pi$

Џll Article views: 861

Q View related articles ¿

4 Citing articles: 6 View citing articles ¿ 


\title{
The Coming of an Ice Age? Turkish- Israeli Relations Since 2002
}

\author{
ILKKER AYTÜRK \\ Department of Political Science, Bilkent University, 06800 Ankara, Turkey
}

\begin{abstract}
Turkish-Israeli relations, which had reached the level of strategic cooperation by the end of the 1990s, started to decline after 2000 and Turkey's approach to Israel has changed considerably as a result of huge transformations in international, regional, and Turkish domestic politics. The Israeli Operation Cast Lead in December 2008-January 2009 and the "One Minute" incident at Davos in January 2009, however, initiated a continuous crisis situation, which reached its peak in the May-June 2010 Mavi Marmara crisis. This article aims to analyze the causes of change in the Turkish perception of Israel by focusing on three key factors: Justice and Development Party ideology and actors, power vacuum in the Middle East, and Turkish foreign policy discourse of grandeur.
\end{abstract}

More than 60 years have passed since Turkey recognized the State of Israel diplomatically, but one constant, structural factor continues to dominate the tone, pace, and intensity of bilateral relations and, particularly, the Turkish policy-making. It has now become an established fact that Turkey's relationship with Israel is fundamentally pegged and extremely sensitive to the ups and downs in the Arab-Israeli and Israeli-Palestinian conflicts. An uncharacteristic era of rapprochement between Israel and its Arab neighbors during the first half of the 1990s had contributed immensely to the forging of very close relations between Turkey and Israel. Likewise, a series of setbacks in the peace process, namely the failure of peace talks at Camp David in 2000, Ariel Sharon's subsequent visit to the Temple Mount/Haram al-Sharif, and the beginning of the second intifada, led all observers to expect an Ice Age in the Turkish-Israeli relations. After all, strategic ties with Israel had again become a source of embarrassment for Turkey and were destined to be downgraded to unassuming proportions. Yet, no one anticipated this to happen with so much drama and noise.

Since the outbreak of the Mavi Marmara crisis in late May 2010, bilateral relations between the two countries are in the emergency room, and if Turkey and Israel are still on talking terms, that is only thanks to persistent American intervention. Although the crisis situation may not be terminal, under the current circumstances,

Correspondence Address: İlker Aytürk, Department of Political Science, Bilkent University, 06800 Ankara, Turkey. Email: ayturk@ bilkent.edu.tr 
neither the USA nor Israel hopes for a full normalization, but both countries are willing to settle for a modus vivendi agreeable to them. What went wrong? How and why did Turkish-Israeli relations touch bottom? Could it have been otherwise? Is the growing estrangement between the two countries due to ideological convictions which dominate policy-making actors? Or, are there more profound, impersonal, and structural factors at play here? Does this crisis situation between Turkey and Israel constitute an anomalous situation in Turkish foreign policy, the guiding principle of which has been "zero-conflict with the neighbors" under Foreign Minister Ahmet Davutoğlu? Or, is sacrificing relations with Israel a natural outcome of the Justice and Development Party (AKP) policy, a price to be paid for Turkey's grand return to the Middle East? What are the implications of this crisis between Turkey and Israel for Turkish-American and Turkish-EU relations? This article aims to respond to these questions by focusing, especially, on the developments that had taken place after 2009.

\section{Second Intifada to Mavi Marmara: A Synopsis of Turkish-Israeli Relations}

Most factors which made the Turkish-Israeli alliance possible in the 1990s disappeared one by one after 2000. First, the failure of the Camp David talks during the same year and the uncontrollable deterioration of the Israeli-Palestinian relations immediately following the second intifada made Turkish leadership extremely sensitive to Arab-Muslim and, to a certain extent, Turkish public opinion. When the Palestinian leader Arafat was virtually imprisoned in his government compound in Ramallah and Israeli operations in the territories took a huge toll on the Palestinian civilian population, Turkish policy-makers perceived their ties with Israel as a burden rather than as an asset. As a matter of fact, this mood was widespread even before the AKP's electoral victory in 2002, as is evidenced by Prime Minister Bülent Ecevit's condemnation of Israeli policies as "genocidal" in response to the Operation Defensive Shield in March 2002. ${ }^{1}$ The AKP governments after 2002 continued this line of policy and, on a number of occasions, Prime Minister Recep Tayyip Erdoğan accused Israel of murdering civilians indiscriminately, which amounted to "state terrorism." 2 Second, while the Turkish-Israeli alliance helped to squeeze Syria into submission and ejecting the Kurdish Workers' Party (PKK) and its leader Abdullah Öcalan, thereby eliminating Syria's PKK card, the very success of this alliance ironically removed a building block of the alliance itself. Following the ouster of Öcalan, Syria quickly became a close ally and the linchpin of Turkey's new Middle East policy and Israel's stature in Ankara deteriorated even further. Finally, electoral victories of the AKP in 2002 and 2007 signaled a gradual shift of power from the secular military to a conservative and mildly Islamist elite, which adopted a pragmatic but instinctively cool approach toward Israel.

The pragmatism aspect needs further elaboration, because it shows that, at least until 2009, Erdoğan did not necessarily consider Israel a rival or an enemy. Even before the AKP won the elections in 2002, Erdoğan and his team of advisors actively engaged American-Jewish organizations such as Jewish Institute for National 
Security Affairs, American-Israel Public Affairs Committee, and Anti-Defamation League for seeking their support in congressional politics. Erdoğan went so far as to accept occasional honors and awards from these organizations, which cost him political capital at home. ${ }^{3}$ Indeed, Turkey's loud criticism of Israeli policies did not hinder very close cooperation between the two countries in the form of arms deals and intelligence-sharing. Furthermore, Ariel Sharon's decision to pull out from Gaza in 2005 initiated a positive environment during which Turkey actively sought a mediator role between Israel and the Arab-Muslim world. That year, Turkish diplomats prepared the ground for a meeting between Israeli and Pakistani foreign ministers in İstanbul, ${ }^{4}$ and such efforts continued unabated from then on, particularly in the Israeli-Palestinian and Israeli-Syrian tracks. ${ }^{5}$ It needs to be added that Israel complied with Turkish demands for mediation for three reasons:

(1) Refusing Turkish mediation would have further alienated Ankara at a time when the logic of the Turkish-Israeli relationship was being questioned more and more.

(2) From 2005 to 2009, Turkey still acted as a neutral arbiter whom all the parties to the conflict could trust.

(3) By 2005, Turkey had already started to become a major regional power and Israel hoped that Turkish mediation would pull the rug from under the feet of the Iranians and limit their influence over Syria, Lebanon, and Hamas.

In what constituted a major revision of the traditional Turkish approach to the Middle East, the AKP stamp on Turkey's new foreign policy was visible in assertive Turkish involvement in emerging crises: negotiations with Hamas over the fate of the kidnapped Israeli soldier, Gilad Shalit; dispatch of a Turkish team of professionals to investigate the situation, when the entire Muslim world was inflamed by Israeli excavations near the Mughrabi Gate in Jerusalem's Old City; and, most importantly, the opening of Turkish-led, indirect mediation between Israeli and Syrian representatives in Turkey in May 2008. ${ }^{6}$ Mediated talks between Israel and Syria were said to be close to a successful breakthrough, when negotiations as well as Turkish-Israeli relations collapsed unexpectedly in the aftermath of the Operation Cast Lead (December 2008-January 2009) in Gaza Strip.

Turkey reacted very sharply to the Israeli operation because of the increasing number of civilian casualties and as a result of a feeling of betrayal. Prime Minister Erdoğan openly declared that he lost confidence in the then Israeli Prime Minister Ehud Olmert, who did not inform him about the impending operation, and that Olmert was no longer regarded by Turkey as a partner for peace. ${ }^{7}$ In a famous speech, Erdoğan scolded world media for being controlled by Israel, asked how Israel could still keep its seat in the UN, and addressed the Israelis in Hebrew by making a reference to the Sixth Commandment of the Decalogue, "Lo tirtsach" (Thou shall not kill). ${ }^{8}$ There is no doubt that Erdoğan's anger could, to a certain extent, be attributed to the fact that he saw the Israeli operation as a personal affront, and also to the annihilation of the environment of peace and stability in 
the region, which had facilitated Turkey's role as a mediator in regional conflicts since 2005 .

From then on, bilateral relations between Turkey and Israel were tested at an accelerated pace. After the verbal spat between Prime Minister Erdoğan and Israeli President Shimon Peres at Davos in January 2010, Israelis began to fathom the seriousness of the crisis, but chose to respond by flexing their muscle. Israel's Deputy Foreign Minister Majallie Whbee told press reporters that if Turkish critics continued to call the operation in Gaza a genocide, then they would "recognize the Armenianrelated events as genocide," too." Israel's Ground Forces Commander Major General Avi Mizrahi spoke to an international audience in February 2010 and said that Turkey did not have moral superiority to teach Israel a lesson in human rights as long as it did not take care of its own domestic problems, which Mizrahi named as "the massacre of Armenians, the suppression of the Kurds and the occupation of Northern Cyprus." ${ }^{\prime \prime}$ While an apology was later extended for Mizrahi's remarks, it is extremely unlikely that he spoke only his mind and without prior authorization. ${ }^{11}$

There followed a brief period of lull which lasted until the autumn of 2009, which led some observers to believe that a process of damage control was underway and that Turkish and Israeli leaders would not let further deterioration. ${ }^{12}$ Foreign Ministers Ali Babacan and Tzipi Livni met in early March ${ }^{13}$ and Turkish President Abdullah Gül sent a personal envoy to meet President Peres. ${ }^{14}$ There were even reports in the Turkish press that Gül was planning a presidential visit to Israel to mend bilateral ties. ${ }^{15}$ However, the gravity of the crisis came out into the open in October 2009, when Prime Minister Erdoğan refused to allow Israeli participation in the regularly held Anatolian Eagle military exercises, arguing that if his voters do not want an alliance with Israel, he would not want it either. ${ }^{16}$ Although the USA, too, pulled out of the exercises in protest of the Turkish decision, Erdoğan did not budge and, in doing so, he sent a very important message to Israel and the USA that his harsh words at Davos were not mere rhetoric. The crisis was spilling over: Turkey was no longer going to condemn Israel and continue business as usual. On the contrary, Ankara now seemed ready to take one step forward and did not hesitate to downgrade the ties between Turkish and Israeli militaries.

Two seemingly minor incidents, caused by two TV series in Turkey, further exacerbated the problem. In October 2010, TRT Channel 2, a public TV channel in Turkey, began broadcasting a drama series, called Ayrllık (Separation), depicting Israeli Defense Forces (IDF) soldiers as demonic murderers of Palestinians in the Occupied Territories. What particularly offended Israel was the fact that Ayrllk was filmed specifically for the state-funded Turkish public television. ${ }^{17}$ Broadcasting discontinued after Israeli protests, but soon a similar crisis erupted over another TV series, shown on a private Turkish TV channel. The Kurtlar Vadisi (Valley of the Wolves), which has long been controversial in Turkey, too, ${ }^{18}$ drew from several anti-Semitic themes in one of its episodes, hurting Israeli public opinion and prompting the Israeli government to react more strongly this time. What started out as and could have remained a diplomatic protest, however, snowballed into a major crisis, 
when the Israeli Deputy Foreign Minister, Danny Ayalon, seated the Turkish ambassador, Oğuz Çelikkol, on a low couch, refused to shake his hand, and made a point of this before TV cameras. This move, which was meant to humiliate Ambassador Çelikkol, enraged the Turkish leadership and public opinion and deepened the rift between the two countries. Ayalon sent a formal apology to the Turkish ambassador after the intervention of President Peres, ${ }^{19}$ but too much damage was already done. Israeli Defense Minister Ehud Barak rushed to Ankara the following week to repair the ties, but to his chagrin, he could not meet President Gül and Prime Minister Erdoğan and had to make do with meeting Foreign Minister Davutoğlu only. ${ }^{20}$

The Mavi Marmara crisis in late May 2010 was the last straw which broke the camel's back and is a textbook example of gross miscalculation and mismanagement on both sides. The ship was purchased by İnsan Hak ve Hürriyetleri İnsani Yardım Vakfi (IHH), a Turkish-Islamic NGO, and joined an international flotilla with hundreds of activists on board, who aimed at breaching Israel's naval blockade of Gaza with an act of civil disobedience as part of the Free Gaza Movement. Early in the morning of May 31, 2010, the Mavi Marmara was still in international waters en route to Gaza when Israeli commandos stormed the ship. What exactly happened on the deck is still a source of controversy, but in the ensuing fight, one Turkish-American and eight Turkish activists were killed with live bullets and dozens were injured severely, including several IDF soldiers. ${ }^{21}$

In the aftermath of the Davos fracas, one author had quoted Ecclesiastes 3:7 to express his optimism about the future of the Turkish-Israeli relations: if that was a time to rend, there would come a time to sew. ${ }^{22}$ The Mavi Marmara crisis, however, showed that such optimism was unfounded, because it changed the parameters in which both Turkey and Israel had been operating. Not only was the fabric of the bilateral relationship completely rent, but now it was also soiled with blood. This was the first time in republican Turkish history that Turkish civilians had been killed by foreign troops. This fact changed the rules of the game and had two important consequences. To begin with, whereas Turkish public opinion had always supported the Arab countries and the Palestinians in the course of the Arab-Israeli conflict, official Turkish foreign policy carefully avoided entanglement and maintained a middle-of-the-road approach. Yet, because Turkish civilians were killed by Israeli troops on the Mavi Marmara, many Turks now believed that Turkey had become a party to the Arab-Israeli conflict, which they used to watch from a comfortable distance. Secondly, Turkish public opinion had been more or less apathetic about Turkey's alliance with Israel since the 1990s. Not so surprisingly, there had always been considerable sympathy for Israel among secular Turks, particularly among the staunchly secular military. Israelis were admired for their military, economic, and technological prowess, for surviving astonishingly in a nasty neighborhood, and for being a successful example of modernization in the Middle East. The tide has now turned decisively against Israel. It is true that Prime Minister Erdoğan and the AKP leadership have contributed their share to the escalation of the crisis since the beginning of 2009. But, as things stand now, it would be 
unrealistic to expect any Turkish government to restore bilateral relations to normal when Turkish public opinion opposes it.

After getting the UN Security Council to condemn Israeli behavior, albeit in a very mild wording, ${ }^{23}$ in June 2010, Turkish government announced that it would not appoint a new ambassador to Tel Aviv—-the former ambassador, Oğuz Çelikkol, was called back home for consultations after "the low-seat crisis" in January-and set four conditions for the normalization of Turkish-Israeli relations. The conditions were as follows:

(1) Israel had to apologize officially for its handling of the Mavi Marmara affair.

(2) Compensation had to be paid to the families of the dead and to those who were wounded.

(3) Israel had to accept the mandate of an international team of investigators.

(4) The "illegal" blockade of Gaza Strip had to be removed. ${ }^{24}$

The content of these demands has changed somewhat during the course of the following months due to intense US pressure, but the Turkish demand for an official apology has remained a staple of all covert—but exposed-negotiations between Turkey and Israel.

The fallout from the Mavi Marmara crisis damaged vital Israeli and Turkish interests. Israelis witnessed a temporary disintegration of the anti-Iranian bloc which they struggled so hard to build and how international public opinion shifted away from the question of Iran's nuclear plans to the crisis in the Mediterranean. Its trigger-happy handling of the flotilla also invited increased American pressure and unnecessarily added to the already existing tension in American-Israeli relations. Furthermore, the killing of nine activists in international waters, which Turkey called "an act of banditry and piracy," dented Israel's image globally and played a major role in its perception as a "crazy democracy" 25 rather than Israel's claim to be the only democracy in the Middle East.

Turkey's conundrum is not less stressful. In a fateful twist of history, the Mavi Marmara crisis overlapped with Turkey's vote against the Western bloc at the UN Security Council on the question of measures to be taken against Iran's nuclear program. When put together, the two key decisions - to let Mavi Marmara sail to Gaza and the pro-Iran vote at the UN-raised a red flag in the American and other NATO capitals that began to suspect that Turkey was now following a more independent course and adopting a "Gaullist" foreign policy ${ }^{26}$ Therefore, the most important, negative, outcome of the Mavi Marmara crisis for the Turkish foreign policy was the souring of Turkish-American relations. To the chagrin and surprise of the AKP leadership, who expected unanimous support for Turkey in all international forums, the USA worked hard to prevent a harsh condemnation of Israel at the UN and, then, voted against the UN Human Rights Council Report on the flotilla crisis. ${ }^{27}$ Suat Kınıklığlu, a member of Turkish parliament from the AKP and chairman of the Turkish-American inter-parliamentary friendship committee, visited Washington, DC, in October 2010 and observed that while the White House, the State Department, 
and the Pentagon displayed a relatively more cooperative attitude, "the atmosphere at the Congress [was] truly somewhat unpleasant." 28

Secondly, the Mavi Marmara crisis showed that Turkish foreign policy vis-à-vis Israel and the Arab-Israeli conflict was no longer in harmony with the EU approach either. It is true that the EU countries often hold diverging opinions with respect to the Middle East, but their opposition to the Turkish involvement in the flotilla crisis united them during the discussions over the UN Human Rights Council Report. All EU state representatives, who were members of the Council, abstained during the vote,$^{29}$ which severely undercut the Turkish argument that international law is on the Turkish side. Turkish foreign policy did not find favor in the eyes of the Sunni Arab regimes, either, who were concerned that Turks were now pronouncing the word "Gaza" much more than "Palestine" and that Prime Minister Erdoğan and Foreign Minister Davutoğlu were giving too much publicity to Hamas at the expense of the Palestinian leadership in the West Bank. ${ }^{30}$ Ironically, Syria was unhappy, too, because it had lost an important leverage over the Israelis, provided by Turkey since $2008 .{ }^{31}$ Indeed, by coming to blows with Israel, Turkey squandered the most important instrument of its activism in the Middle East, that is, its mediation role between Israel and the Arab-Muslim world.

\section{What Went Wrong?}

As this brief synopsis of the deterioration in Turkish-Israeli relations shows, too many things went wrong at all critical junctures during the past three years, and if the frenetic last-minute attempts by Turkey and Israel in summer 2011 to find common ground are to be judged as an admission of flawed logic and mistaken policies, then it appears that both countries have to shoulder part of the responsibility.

Since 2000 or so, Israeli policy-makers fixed their gaze on the Iranian nuclear program. Given Israel's public culture of according enormous significance to security problems, this did not surprise anyone. What made this fixation on Iran rather problematic for Israel, however, was the way the preoccupation with Iran sidelined all other issues on the Israeli agenda. Even the Arab-Israeli conflict was now regarded as secondary in importance and, naturally, the relationship with Turkey was placed on the low-burner. Israelis hoped that it would continue to simmer slowly until the Iranian threat would be taken care of and, therefore, they failed to nurture the relationship with Turkey at a time when alarm signals beeped almost constantly.

The fact of the matter is that Israeli policy-makers failed to comprehend massive changes taking place in Turkey after the year 2000. They did not understand the significance of the economic crisis of 2001, which completely delegitimized the ruling elite that had forged the Turkish-Israeli alliance. They failed to give meaning to the slow but steady decline in the power of the Turkish military, which had been Israel's main contact in Turkey. Probably, all these developments on the ground were noted by the Israelis and even discussed, but they did not seem to have tied them together to form a big picture. As late as February 2009, Israeli public opinion chose to believe reports of anonymous Turkish military officers 
who reassured them that Prime Minister Erdoğan's rhetoric need not be taken seriously. ${ }^{32}$

If their strategic cooperation with Turkey were so dear to Israelis, they should have interpreted Prime Minister Erdoğan's outburst at Davos as a wake-up call. At Davos, a very critical psychological threshold was passed and huge demonstrations on the Turkish street were a testimony to the fact that more was to come. At that point, a much wiser policy for Israel would have been to establish mechanisms for damage control and to pursue this policy very aggressively and persistently until they could convince their Turkish counterparts that Israel is indeed committed to maintaining the former level of strategic ties with Turkey. That was the moment to engage Turks with a very frank discussion over existing problems and to iron them out. Instead, Turkey was treated to a show of Israeli muscle as in the cases of the threat to recognize the Armenian genocide, Maj. Gen. Mizrahi's polemics, the low-seat crisis and, finally, Israel's botched operation on Mavi Marmara. Israelis seem to attach great importance to their alliance with Turkey and regard the current situation as strategically damaging to Israel's interests, but, on the other hand, their policy visà-vis Turkey since 2009 is characterized by a lack of sensitivity.

The Turkish approach to Turkish-Israeli relations was problematic, as well. A short clarification needs to be added in order to understand who shaped Turkish decision-making in the aftermath of the Israeli Operation Cast Lead. Until that point, Turkey's Israel policy could be said to have been decided by two groups of actors: the government and the military. After 2009, however, the initiative seems to have passed entirely into the hands of the government, while the military keeps silent either because of the erosion in its power or, maybe, because it, too, is no longer interested in maintaining the same level of security cooperation with Israel just like the government. In any case, Prime Minister Erdoğan and Foreign Minister Davutoğlu had a free hand in making key decisions during this period and did not share responsibility with any other domestic actor.

Two of these key decisions fanned the flames of conflict and aggravated the crisis situation. The first was Prime Minister Erdoğan's declaration in early January 2009 that as a result of the Operation Cast Lead, Turkey decided to end its mediation efforts between Israel and Syria. There could have been other ways to respond to the Israeli operation that did not blow up an edifice which took more than a decade to build. Instead of starting an all-out verbal attack on Israel and matching rhetoric with actions, Turkey could have remained faithful to its policy of condemning Israeli behavior, on the one hand, and still engaging Israel to continue its mediation efforts. The second, and certainly more significant, Turkish decision, on the other hand, was the government's green light to the IHH, which organized the flotilla movement, and to let Mavi Marmara sail from Turkey. Foreign Minister Davutoğlu tried to justify this decision by claiming that Turkey is a democratic state and that democratic states cannot give instructions to NGOs. ${ }^{33}$ However, this justification is not so convincing. For instance, if IHH had decided to send a flotilla of buses to help Muslim Chechens instead of Hamas-led Gaza, there is no doubt that the Turkish government would have done everything possible to prevent departure so 
as to not antagonize its irritable northern neighbor. In any case, the effectiveness of the Turkish government's influence over IHH and that it has no qualms about "convincing" NGOs became public as a result of the cancellation of the 2011 flotilla voyage to Gaza.

Which factors explain the political and ideological context of these two decisions? What accounts for Prime Minister Erdoğan's and Foreign Minister Davutoğlu's resolve to push Israel to the corner? There are three major dynamics which could shed light on Turkish decision-making during the past three years.

\section{Ideology and Actors}

It is no secret that the AKP leadership has deep roots in Turkey's Islamist movement. Political socialization of both Prime Minister Erdoğan and Foreign Minister Davutoglu took place in the 1970s and 1980s during the Islamist struggle against the Turkish establishment. The Milli Görüş movement, which Erdoğan used to belong to, wasand still is-both anti-Semitic and anti-Israel. Erdoğan acted very pragmatically, however, when he and a close group of associates founded the AKP in 2001 and declared that they were giving up on their Milli Görüş background and adopting a conservative democrat line, which would be in harmony with the 21 st-century democratic ideals. Most probably, Erdoğan never changed his mind and had no liking for Israel throughout, but his pragmatism was not fake either. This is best illustrated by his willingness to assume a more active role in bringing Israel to the table for negotiations. Most crucially, he succeeded in doing this while keeping Turkish neutrality. The switch from neutral to rival took place after 2009, when Erdoğan was now encouraged by the positive response of the Turkish electorate and, simultaneously, did not feel constrained by the international community. Davutoğlu's standpoint, on the other hand, is less complicated. Although a pro-government Turkish think tank, SETA, attempted to call his views on Israel "value-based realism" (de ğer eksenli realizm), ${ }^{34}$ Davutoğlu's approach to Israel has not been characterized by Realpolitik concerns so far; on the contrary, ideology seems to matter more than anything else in his thinking. Reports in the Israeli press that he advocated a PalestinianJewish bi-national state in private meetings have been flatly denied by the Turkish Ministry of Foreign Affairs. ${ }^{35}$ His statement at a meeting of Arab foreign ministers that "Jerusalem will soon be a capital and we shall all go and pray at al-Aqsa,"36 however, has not been denied and shows the extent to which Islam and foreign policy are intertwined in Davutoğlu's Weltanschauung. Turkey's current Israel policy is shaped by this interesting, and occasionally tense, ${ }^{37}$ relationship between Erdoğan, the pragmatic, and Davutoğlu, the ideologue.

\section{Power Vacuum in the Middle East}

Israel's Operation Cast Lead in December 2008-January 2009 elicited feeble protests from Egypt, Saudi Arabia, Jordan, and the Gulf countries, which were actually happy to see Hamas pummeled since they considered it a pawn of Iranian influence in 
the region. While emotions ran high on the Arab street, many Arab capitals seemed to have reached a tacit understanding with Israel on the need to contain Iran and its allies. Erdoğan and Davutoğlu capitalized on this power vacuum and regarded it as an invaluable opportunity to stage Turkey's grand return to the Middle East. The "One Minute" incident at Davos, which was probably unplanned, and various other bold Turkish moves to corner Israel could be seen as gestures to the Arab street, which made Erdoğan a regional folk hero as much as they endeared him to the Turkish voters.

\section{Discourse of Grandeur}

One final factor which created an environment conducive for these two decisions was an idiosyncratic foreign policy discourse which dominated Turkish press and policymaking circles after 2008. This discourse was put into currency by pro-government think tanks and foreign policy pundits in the Turkish press. Essentially speaking, this large group of think tank analysts and journalists emphasized growing Turkish power in the Middle East and the world at large and contrasted Turkey with what they called an isolated and considerably weaker Israel, "which could no longer read the impetus for change in the Middle East." ${ }^{38}$ According to their logic, Israel's dependence on Turkey was so great that it would absorb blow after blow without being able to raise a finger against Turkey. As a matter of fact, they thought that they were proven right because on a number of occasions the Israelis indeed apologized officially for untoward actions.

The decisions to both end mediation efforts and permit Mavi Marmara's departure were regarded as litmus tests for the confirmation of Turkish dominance over Israel, because it was taken for granted that Israel had no choice but to yield to Turkish pressure. These conjectures were right to the extent that Turkey had indeed become a force in its region to be reckoned with in the last decade. But these foreign policy pundits were acting on a false premise when they assumed that Israel today is a shadow of its former self. That these conjectures were partly wrong is what we have been witnessing in the enfolding events since the Mavi Marmara crisis. In other words, if Turkey could step on Israeli toes, Israel has shown that it could pay back in kind, as well.

\section{Conclusion}

The Turkish-Israeli strategic partnership had been forged under the special circumstances of the 1990s, but, interestingly enough, it had withstood cataclysmic changes in those circumstances from 2000 to the end of 2008. The damage done to the strategic relationship since then is most probably irreversible, however, which explains the Israeli reluctance to apologize for the bloodbath on the deck of Mavi Marmara. What both countries and the USA hope for at the moment is at best a normalization of bilateral relations, that is, an end to the fiery rhetoric and the return of a Turkish ambassador to Tel Aviv. 
Both Turkey and Israel have shown some flexibility since summer 2010 and have come to the conclusion that further deterioration is not in their best interest. The loss of Turkey shocked the Israeli policy-makers and catapulted the question of the future of the relationship to the top of Israel's policy agenda. Gone are the days when the question was comfortably neglected or overshadowed by more pressing problems with Iran. Furthermore, Israel has started a process of easing the blockade on Gaza Strip and accepted, in principle, to pay an indemnity to the families of those who were killed on Mavi Marmara. Turkey, on the other hand, has slowly moved from its originally intransigent position and is now seeking an accommodation with Israel. The initial ultimatum after the Mavi Marmara crisis that if Turkish demands are not met within a "reasonable" period of time, Turkey would downgrade its level of representation ${ }^{39}$ in Tel Aviv-from a technical point of view, Turkey has not appointed a new ambassador to Tel Aviv since the recall of Oğuz Çelikkol in January 2010, but its representation is still at the ambassadorial level-has not been carried out. Turkey did not refuse to talk to Israel and delegations have met and been negotiating over the details of a face-saving formula. ${ }^{40}$ Prime Minister Erdoğan made a personal gesture of friendship by sending Turkish planes to help fight forest fires in northern Israel. ${ }^{41}$ Negotiations have been deadlocked over the thorny issue of an official Israeli apology, which Turkey demands as a fundamental point of departure and Israel withholds for various reasons. ${ }^{42}$

After a very stormy three years, the Turkish-Israeli relationship has sunk so low that it could be rescued only by a paradigmatic shift in global or regional politics. If the Arab Spring, which has so far led to a reshuffling of power configuration and alliances in the Middle East, does not provide such an opportunity, there is every reason to expect an Ice Age descending on the Turkish-Israeli relations.

\section{Notes}

1. "Ecevit'ten Soykırım Açıklaması," Radikal, April 5, 2002.

2. "Erdoğan: Devlet Suikast Yapmaz," Sabah, June 4, 2004.

3. Jon Gorvett, "Erdogan's Third U.S. Visit Comes Closest to Being a Charm," Washington Report on Middle East Affairs (April 2004), pp. 38-9.

4. Murat Yetkin, "İsrail-Pakistan Buluşmasının Perde Arkası Neydi?" Radikal, September 14, 2005.

5. Meliha Altunışık and Esra Çuhadar, "Turkey's Search for a Third Party Role in the Israeli-Syrian and Israeli-Palestinian Conflicts: A Neutral Facilitator or a Principal Power Mediator?" Mediterranean Politics, Vol. 15 (2010), pp. 371-92. An Israeli specialist on Turkey, Dr Anat Lapidot-Firilla, described Turkish willingness for mediation in the Middle East as "The Turkish man's burden," finding a Kiplingesque flavor in the new trend in Turkish foreign policy; see Anat Lapidot-Firilla, "What is behind Turkey's Antagonism to Israel?," Haaretz, February 21, 2009.

6. Serhat Erkmen, "Suriye-İsrail Görüşmeleri ve Türkiye'nin Rolü," www.asam.org.tr; Tovah Lazaroff, "Olmert: I Was Close to a Meeting with Syrian FM," Jerusalem Post Online Edition, February 26, 2009; Zvi Bar'el, “Olmert ve-Asad sohahu sha' ot be-telefon be-emtsa ‘ut Erdoğan,” Haaretz, February 13, 2009.

7. "Erdoğan İsrail Başbakanı'na Sert Çıktı," Sabah, February 18, 2009.

8. "Lo tir'tsach (Öldürmeyeceksin)," Hürriyet, January 17, 2009.

9. Sean Gannon, "Genocide by Any International Standard," Jerusalem Post Online Edition, February 12, 2009. The editorial article in Haaretz on February 16, 2009, disapproved of the Foreign Ministry's 
threat and invited Israeli politicians to hold the higher moral ground: "The debate is not whether to define the killing of Armenians as genocide or a holocaust. This is a moral issue that obligates us to re-examine history and offer a value-based judgment. ... If Israel seeks to alter its stance on the question of the murder of the Armenians, it would be wise to do so at a more appropriate time, from a worthy position of morality and not as a way to make threats. It should not happen whenever a disagreement erupts with Turkey." See "Shimush tsini be-musar," Haaretz, February 16, 2009.

10. Herb Keinon, “Turkey Irked by IDF General's Remarks," Jerusalem Post Online Edition, February 14, 2009; Barak Ravid and Yossi Melman, "Shagrir Yisra'el be-Ankarah zuman le-sihat havharah beekvot divrei ha-aluf Avi Mizrahi," Haaretz, February 14, 2009.

11. Yaakov Katz, "IDF Head 'Sorry' General Slammed Turks," Jerusalem Post Online Edition, February 19, 2009.

12. İlker Aytürk, "Between Crises and Cooperation: The Future of Turkish-Israeli Relations," Insight Turkey, Vol. 11, No. 2 (2009), pp. 57-74.

13. "Babacan ve Livni Bir Araya Geldi: Davos’tan Sonra İlk Buluşma," Şalom, March 11, 2009.

14. "İşadamı Jak Kamhi Peres İle Görüştü," Sabah, February 19, 2009.

15. "Cumhurbaşkanı Gül İsrail’e Gidecek," Milliyet, February 27, 2009.

16. “One Minute'un Ardından Anadolu Kartalı Gerilimi," Radikal, October 12, 2009.

17. "Ayrılık Krizi," Yeni Şafak, October 16, 2009.

18. Lerna Yanık, "Valley of the Wolves-Iraq: Anti-Geopolitics Alla Turca," Middle East Journal of Culture and Communication, Vol. 2 (2009), pp.153-70.

19. Barak Ravid, "Peres: Humiliation of Turkey Envoy Does Not Reflect Israel's Diplomacy," Haaretz, January 13, 2010.

20. “İsrail Savunma Bakanı Ankara'da," Hürriyet, January 17, 2010.

21. For the IHH's version of events, see Palestine Our Route, Humanitarian Aid Our Load: Flotilla Campaign Summary Report (İstanbul: İnsani Yardım Vakfı, nd).

22. Aytürk (2009), p. 66.

23. Harriet Sherwood and Matthew Weaver, "UN Calls for Inquiry into Israel Flotilla Attack," Guardian, June 1, 2010.

24. "Full Text of Turkish FM Davutoğlu's Speech in UN Security Council," Today's Zaman, June 1, 2010.

25. Zvi Bar'el, “Israel Uses 'Crazy Democracy' to Justify Security Needs," Haaretz, July 10, 2011.

26. Ömer Taşpınar, "The Rise of Turkish Gaullism: Getting Turkish-American Relations Right," Insight Turkey, Vol. 13, No. 1 (2011), pp. 11-7; Carol Migdalowitz, “AKP's Domestically-Driven Foreign Policy," Turkish Policy Quarterly, Vol. 9, No. 4 (2010-11), pp. 37-45.

27. Colum Lynch, "U.N. Panel Endorses Report Accusing Israel of Executions Aboard Aid Flotilla," Washington Post, September 30, 2010.

28. Yıldız Yazıcığlu, "Kınıklığlu: İsrail'i Tartışmasız Savunan Çevreler Var," www.turkishny.com/ interviews/40-interview, accessed on October 14, 2010.

29. Lynch, "U.N. Panel Endorses," Washington Post, September 30, 2010.

30. Mubarak's Egypt was particulary annoyed by Turkey's warm relationship with the Hamas.

31. "Esad İsrail'le Türkiye'nin Arasının Bozulmasından Rahatsız," www.pressmedya.com/haber_detay. asp?haberID=2567.

32. Zvi Bar'el, "Why We Need Turkey," Haaretz, February 22, 2009.

33. Interview with Ahmet Davutoğlu, "İsrail’le 2. Mavi Marmara Krizi Kapıda," www.aktifhaber.com/ israille-2.-mavi-marmara-krizi-kapida-445316h.htm.

34. Seta 2010 Yıllı̆̆ (Ankara: SETA, 2011), pp. 102-04.

35. "İsrail Gazetesinin İddiasını Dışişleri Sözcüsü Yalanladı," Star, November 29, 2010.

36. Aslı Aydıntaşbaş, “Davutoğlu: Bir Gün Mescid-i Aksa'da Namaz Kılacağız,” Milliyet (June 14), 2010.

37. The tension between the two became most visible after the Mavi Marmara incident and the UN Security Council vote, when Erdoğan's former spokesman, Akif Beki, penned a very critical article about Davutoğlu; see Akif Beki, “Davutoğlu’nun ‘Ben’ İdraki,” Radikal, June 15, 2010.

38. Ufuk Ulutaş, Reclaiming Israeli-Syrian Talks, SETA Report No.2, October 2009; Ufuk Ulutaş, The 2009 Israeli Elections and Turkish-Israeli Relations, SETA Brief No. 31, February 2009; Ufuk 
Ulutaş, Turkey-Israel: A Fluctuating Alliance, SETA Brief No. 42, January 2010; Ufuk Ulutaş, Turkey and Israel in the Aftermath of the Flotilla Crisis, SETA Brief No. 43, June 2010; Osman Bahadır Dinçer and Gamze Coşkun, İsgalin Bir Diğer Adl: Yahudi Yerleşimleri, USAK, August 2010; Sedat Laçiner, "İsrail Türkiye'yi Anlamadı," Star, October 12, 2010; interview with Zeynep Dağı, "İsrail Normalleşmeden Korkuyor," Yeni Şafak, February 12, 2011; Gökhan Bacık, "Turkish-Israeli Relations after Davos: A View from Turkey," Insight Turkey, Vol. 11 (2009), pp. 31-41. For the opposite view, see Şanlı Bahadır Koç, Stratejik Dehlizlerde Derinlik Sarhoşluğu: Bir AKP Dış Politikası Eleştirisi, 21. Yüzyıl Türkiye Enstitüsü Raporu, June 2010.

39. "Türkiye'den İsrail'e Ültimatom," www.stratejikboyut.com/haber/turkiyeden-israile-ultimatom45767.html.

40. Duygu Güvenç, “Ankara Yanıt Bekliyor,” Sabah, December 29, 2010; Duygu Güvenç, “Özür İçin Formül," Sabah, July 3, 2011.

41. "Netanyahu Türk Uçaklarını Ziyaret Etti," Sabah, December 3, 2010.

42. Apart from loss of face in domestic politics and a reluctance to provoke Avigdor Lieberman's party, Israel Beitenu, to bolt the coalition government, there are three basic factors which prevented Israel from apologizing oficially so far: (a) Israel does not want to give up its policy of intercepting vessels in international waters to check their cargo, (b) Israel is alarmed about the possibility that an apology might start an international judiciary process and lead to the prosecution of policymakers and military personnel who were involved in the Mavi Marmara incident, and (c) as of now, there is apparently no Turkish pledge to restore relations back to the former level if an official apology is extended. 